\title{
PENGEMBANGAN INSTRUMEN KEMAMPUAN BERPIKIR KRITIS DAN KEMAMPUAN LITERASI SAINS SISWA KELAS IV SD
}

\author{
I.P.S. Putra ${ }^{1}$, I.W. Suastra ${ }^{2}$, N.K. Suarni ${ }^{3}$ \\ ${ }^{123}$ Program Studi Pendidikan Dasar \\ Universitas Pendidikan Ganesha \\ Singaraja, Indonesia \\ e-mail: putu.suardika@undiksha.ac.id ${ }^{1}, \frac{\text { iwsuastra@undiksha.ac.id }^{2}}{\text { niketutsuarni@undiksha.ac.id }^{3}}$,
}

\begin{abstract}
Abstrak
Penelitian ini bertujuan untuk (1) mengetahui dan mendeskripsikan validitas intrumen kemampuan berpikir kritis dan instrumen kemampuan literasi sains pada muatan pelajaran IPA SD. (2) mengetahui dan mendeskripsikan reliabilitas intrumen kemampuan berpikir kritis dan kemampuan literasi sains pada muatan pelajaran IPA SD. Jenis penelitian yang digunakan dalam penelitian ini merupakan penelitian pengembangan dan model pengembangan yang digunakan adalah model 4-D yang dikembangkan oleh Thiagarajan (1974). Pengembangannya terdiri dari empat tahap yaitu define, design, develop dan disseminate. Namun pada penelitian ini hanya terbatas sampai tahap develop. Dengan alasan, demi menjaga kesehatan bersama menghindari pandemi virus Covid-19 yang telah menyebar ke seluruh dunia. Hasil penelitian menunjukkan bahwa: (1) Instrumen kemampuan berpikir kritis yang dikembangkan memenuhi syarat validitas isi dengan nilai 1.00 berada pada kategori sangat baik dan sangat layak digunakan. (2) Instrumen kemampuan literasi sains yang dikembangkan memenuhi syarat validitas konten dengan nilai 0,76 yang dinyatakan valid sehingga layak digunakan dalam pembelajaran. (3) Instrumen berpikir kritis yang dikembangkan memenuhi syarat reliabilitas ekpert dengan nilai 0,92 dengan kategori sangat tinggi sehingga layak digunakan dalam pembelajaran. (4) Instrumen kemampuan literasi sains yang dikembangkan memenuhi syarat reliabilitas ekpert dengan nilai 0,94 dengan kategori sangat tinggi sehingga layak digunakan dalam pembelajaran.
\end{abstract}

Kata Kunci : Kemampuan Berpikir Kritis; Kemampuan Literasi Sains; Pengembangan Instrumen

\section{Abstract}

This study aims to (1) study and describe the validity of instruments of critical thinking skills and instruments of sciencetific literacy in elementary science subjects. (2) learning and describing the reliability of the instruments of critical thinking skills andscientific literacy of elementary school natural sciences in elementary science subjects. This type of research used in this research is development research and the development model used is a 4-D model developed by Thiagarajan (1974). Its development consists of four sides, namely defining, designing, developing and disseminating. However, this research is only limited to developing. With the reason, for the sake of shared health, avoid the Covid-19 pandemic virus that has spread throughout the world. The results showed that: (1) The instrument of critical thinking skills developed content requirements with a value of 1.00 depending on the category of very good and very feasible to use. (2) The science learning outcomes instrument developed meets the content validity requirements with a value of 0.76 which is declared valid as suitable for use in learning. (3) Critical thinking instruments developed fulfill reliability requirements with a value of 0.92 with a very high category so that it is appropriate to be used in learning. (4) The science tific literacy instrument developed meets the reliability requirements of express with a value of 0.94 with a very high category that is suitable for use in learning.

Keywords : Critical Thinking Skills; Sciencetific Literacy; Instrument Development 


\section{PENDAHULUAN}

Pendidikan memiliki peranan yang sangat penting dalam meningkatkan dan mengembangkan kualitas sumber daya manusia SDM). Melalui penyelenggaraan pendidikan diharapkan dapat mencetak manusia-manusia berkualitas yang akan mendukung tercapainya sasaran pembangunan Nasional. Untuk dapat mewujudkan pendidikan yang berkualitas, maka pengembangan pendidikan pada Abad ke 21 harus dilaksanakan dengan berstandar pada empat pilar pendidikan sebagaimana yang telah direkomendasikan oleh UNESCO yaitu learning to know, learning to do, learning to be, dan learning to live together, selanjutnya, Dantes (2010) menambahkan satu pilar lagi yaitu, learning to live sustanabilies, yang memaknai bahwa peserta didik harus memahami arti kehidupan ini, dan kelangsungan hidup di jagad raya ini, sehingga kelangsungan hidup umat manusia dan dukungan alam yang harmonis dan berkesinambungan dapat diwujudkan.

Salah satu muatan pelajaran yang diberikan pada jenjang sekolah dasar yaitu muatan pelajaran IPA. Muatan pelajaran IPA merupakan salah satu mata pelajaran yang wajib diberikan pada siswa jenjang Sekolah Dasar yang memiliki peranan penting sebagai wujud mempersiapkan siswa dalam mengahadapi kehidupan sehari-hari. Pembelajaran IPA merupakan suatu proses dan rangkaian untuk mempelajari peristiwa-peristiwa yang terjadi di alam dengan melakukan observasi, eksperimentasi, penyimpulan, penyusunan teori agar siswa mempunyai pengetahuan gagasan dan konsep tentang alam sekitar. Lebih lanjut, Suastra (2009: 13-14) menyatakan bahwa hakikat sains/IPA adalah mengembangkan sejumlah kompetensi adaptif yang sesuai dengan perubahan kondisi saat ini menuju kondisi masa depan. Menurut Supriyadi (2009:3) menjelaskan bahwa IPA adalah suatu cara berpikir untuk memahami suatu gejala alam, suatu cara untuk memahami gejala alam, dan sebagai batang tubuh keilmuan yang diperoleh dari suatu penyelidikan. Salah satu tujuan pembelajaran IPA menurut BNSP (dalam Susanto, 2013: 171) yaitu mengembangkan keterampilan proses, rasa ingin tahu, sikap positif dan kesadaran tentang adanya hubungan yang saling memengaruhi antara IPA, lingkungan, teknologi, dan masyarakat. Oleh karena itu, dalam proses kegiatan belajar IPA sangat penting diterapkan untuk menambah pengetahuan siswa dan harus dilaksanakan sesuai dengan strategi yang tepat agar siswa dapat mudah memahaminya.

Pendidikan yang bermutu salah satunya didukung oleh penerapan proses pembelajaran yang berkualitas. Dikatakan bermutu apabila, terjadinya pengkoordinasian dan penyerasian serta pemaduan input sekolah dilakukan secara harmonis dan terpadu sehingga mampu menciptakan situasi pembelajaran yang menyenangkan, mampu mendorong motivasi dan minat belajar dan mampu memberdayakan peserta didik. Penelitian yang dilakukan oleh Linyuan Guo, 2020 pada Faculty of Education University of Prince Edward Island mengungkap bahwa perlu adanya pengintegrasian konsep dalam pengajaran melalui pendekatan holistik dalam mengembangkan kompetensi literasi sains dalam mengusung paradigma pendidikan abad 21 .

Dalam proses pembelajaran, guru merupakan salah satu komponen yang berperan penting dalam menciptakan iklim belajar yang kondusif bagi siswa. Guru juga dituntut untuk terampil dalam merencanakan, melaksanakan dan mengevaluasi proses pembelajaran. Roestiyah (2008:1) menyatakan bahwa "guru harus memiliki strategi agar siswa dapat belajar secara efektif dan efisien untuk mencapai tujuan pembelajaran yang telah ditentukan". Dengan tercapainya tujuan

pembelajaran, maka dapat dikatakan bahwa guru telah berhasil dalam proses mengajar" (Djamarah, 2006:3).

Kemampuan berpikir kritis merupakan kebutuhan yang harus dimiliki 
oleh individu pada era belajar merdeka. Pentingnya kemampuan berpikir kritis tak lepas dari teori kontruk pemikiran dalam kurikulum 2013 menginginkan peserta didik mampu memiliki sebuah daya dalam hal membangun kerangka berpikir kritis, sehingga output yang akan dihasilkan akan benar-benar bergaransi dalam pengembangan keterampilam berpikirnya. Kemampuan ini seringkali tidak diberdayakan oleh guru dalam memahami kemampuan kognitif siswa, sehingga proses pembelajaran yang digunakan oleh guru yang hanya mengandalkan sebuah istilah yang penting pembelajaran berjalan, tetapi guru tidak memahami bahwa bukan hanya dari kemampuan kognitif siswa akan tercapai. Kemampuan seseorang untuk dapat berhasil dalam kehidupannya ditentukan oleh keterampilan berpikir sebagai upaya dalam memecahkan masalah-masalah kehidupan yang dihadapi. Kemampuan berpikir kritis akan mempengaruhi keberhasilan hidup karena terkait apa yang akan dikerjakan dan apa yang abkan menjadi output individu. Mengingat pentingnya kemampuan berpikir kritis banyak upaya yang dilakukan oleh pemerintah yaitu mengintegrasikan kemampuan berpikir kritis ke dalam kurikulum pendidikan. Pembelajaran IPA akan sangat bermakna ketika proses pembelajaran dapat dimengerti dan dipahami oleh siswa. Menumbuhkan rasa ingin tahu siswa yang beda dan mengajarkan mereka untuk berpikir kritis menghadapi masalahmasalah yang ada di dalam pelajaran IPA. Permasalahan yang mampu meransang kemapuan siswa dalam berpikir kritis karena dengan menyelesaikan permasalah padamuatan IPA siswa mampu berpikir secara kritis, logis dan ilmiah sehingga kemampuan mereka dalam berpikir kritis juga dapat terus dikembangkan. Namun pada kenyataannya kemampuan berpikir kritis siswa pada pembelajaran IPA belum sesui dengan yang diharapkan, meskipun pemerintah telah melalukan berbagai upaya untuk menterjadikan dan mengoptimalkan pembelajaran IPA sesuai tujuan. Ini dapat dilihat dari survei
PISA Indonesia menempati peringkat ke 62 dengan nilai rata-rata kemampuan IPA yaitu 403. Dengan demikian menunjukkan bhawa kemampuan problem solving IPA pada peserta didik rendah. (Maulidati, 2018). Hal tersebut menunjukkan bahwa kemampuan berpikir kritis siswa berada pada kategori rendah. Tinggi rendahnya kemampuan berpikir kritis akan berdampak pada hasil belajar siswa.

Kurikulum 2013 yang

mengharapkan siswa untuk
memunculkan kemampuan berpikir kritis dan kemampuan literasi sains dalam evaluasi pembelajaran, maka penilaian yang dapat dibuat guru diharapkan mampu mengarahkan siswa untuk memunculkan kemampuan berpikir kritis dan kemampuan literasi sains dalam membuat pemecahan masalah pada asesmen tersebut. Adapun hasil analisis instrumen yang telah dilakukan di SD Negeri Gugus II Kecamatan Karangasem, didapatkan bahwa instrumen asesmen yang dirancang guru hanya terfokus pada ranah kognitif saja dan masih didominasi pada tingkatan pengetahuan (C1) dan pemahaman (C2), selain itu asesmen saat ini lebih ditekankan pada pemikiran reproduktif, hafalan dan mencari satu jawaban benar terhadap soal-soal yang diberikan. Proses berpikir tingkat tinggi termasuk berpikir kritis dan pengembangan keterampilan literasi sains jarang dilatihkan. Pembelajaran IPA masih menitikberatkan pada pemahaman konsep siswa saja, siswa jarang dilatih untuk memecahkan masalah yang tentunya berdampak pada rendahnya kemampuan literasi sains siswa dan kemampuan berfikir kritis siswa.

Sejalan dengan hal tersebut, Susiawati (2019), yang mengungkap kesulitan guru-guru dalam menyusun instrumen penilaian disebabkan oleh beberapa faktor yakni 1) guru-guru kurang memahami pedoman pembuatan instrumen penilaian, 2) beberapa guruguru tidak mengetahui bahwa rubrik merupakan istilah lain dari pedoman penskoran. 3) kurangnya pemahaman guru-guru mengenai pedoman penyusunan instrumen penilaian keterampilan menyebabkan mereka 
jarang melakukan penilaian keterampilan. Akibatnya, guru menjadi tidak terampil dalam menyusun instrumen penilaian tersebut. 4) rendahnya kreativitas guru juga menjadi kendala dalam penyusunan instrumen penilaian dan 5) guru yang tidak kreatif cenderung hanya mencontoh format-format penilaian yang sudah ada. Akibatnya, tidak mengherankan jika instrumen yang mereka buat kurang jelas atau kurang lengkap. Berdasarkan hasil temuan tersebut menyebabkan instrumen yang digunakan untuk mengukur kemampuan literasi sains dan kemampuan berfikir kritis siswa kurang akurat. Selain hal tersebut data PISA menjadi salah bukti bahwa peserta didik Indonesia berada pada peringkat yang masih rendah dan cenderung tidak mengalami peningkatan dalam 10-15 tahun terakhir. Hasil studi menunjukkan bahwa kemampuan IPA berada di peringkat 72 dari 78 negara. Berdasarkan laporan terbaru Indonesia cenderung menurun jika dibandingkan dengan laporan PISA 2015.

Berdasarkan hal tersebut, peneliti bermaksud mengembangkan instrument untuk mengukur kemampuan berpikir kritis siswa dan literasi sains siswa. Penilaian kemampuan literasi sains yang dikembangkan oleh peneliti dapat digunakan saat proses kegiatan pembelajaran berlangsung. Kemampuan berpikir kritis dapat dilatih untuk siswa dalam menganalisis sesuatu untuk menyelesaikan permasalahan. Melalui kemampuan berpikir kritis, siswa akan mampu menyelesaikan permasalahan di luar kelas seperti membandingkan sesuatu, melakukan evaluasi, dan mampu menggunakan logikanya dalam sebuah diskusi dalam masyarakat. Sedangkan penilaian kemampuan literasi sains siswa akan digunakan untuk menilai kemampuan yang dimiliki oleh siswa sehingga siswa bisa berinteraksi baik dengan lingkungannya melalui penggunaan- penggunaan metode ilmiah. Berdasarkan pemaparan di atas, peneliti tertarik untuk melaksanakan penelitian yang berjudul "Pengembangan Instrumen Kemampuan Berpikir Kritis dan Literasi Sains Siswa Kelas IV SD Negeri di Gugus
II Kecamatan Karangasem Tahun Ajaran 2020-2021.

\section{METODE}

Penelitian ini menggunakan model penelitian dan pengembangan pendidikan (educational research and development) yang bertujuan untuk mengembangkan intrumen kemampuan berpikir kritis dan literasi sains siswa. Sebagaimana dijelaskan oleh Borg and Gall (1989) kegiatan research and development adalah suatu proses penelitian yang bertujuan mengembangkan dan memvalidasi produk-produk pendidikan. Desain penelitian ini menggunakan model pengembangan 4D (four- $D$ ). Menurut Thiagarajan et al (dalam Trianto,2012) model menelitian dan pengembangan model 4D terdiri dari 4 tahapan, yaitu; define, design, develop, dan disseminate atau dapat diadaptasi menjadi 4P, yaitu; pendefinisian, pengembangan, dan penyebaran.

Subyek penelitian ini adalah dua orang dosen pendas dan tiga guru kelas IV SD yang memvalidasi serta mampu memberikan saran, masukan, dan komentar untuk dijadikan bahan revisi terhadap instrumen yang dikembangkan.

Dalam penelitian ini validitas yang diuji yaitu instrumen kemampuan berpikir kritis dan hasil belajar IPA diuji terlebih validasi oleh 3 pratisi dari guru SD dan 2 dosen Pendas. Instrumen disebut valid apabila benar-benar mampu mengukur apa yang semestinya diukur dengan instrumen tersebut (Candiasa, 2010:21).

Validasi dari validator dianalisis menggunakan analisis Isi Validity Ratio (CVR) dengan rumus berikut:

$$
\mathrm{CVR}=(2 n e / n)-1
$$

(Azwar, $2013:$ 114)

Setelah mengidentifikasi setiap sub pertanyaan instrumen dengan menggunakan CVR, maka selanjutnya yaitu menghitung CVI (Isi Validity Index). $\mathrm{CVI}$ digunakan untuk menghitung ratarata dari keseluruhan nilai CVR untuk komponen instrumen kemampuan berpikir kritis dan hasil belajar IPA. Adapun rumus $\mathrm{CVI}$, yaitu sebagai berikut: $\mathrm{CVI}=\left(\sum \mathrm{CVR}\right) / \mathrm{k}$

(Azwar, 2013:115) 
Setelah dilakukan uji validitas, uji selanjutnya ialah melakukan pengujian terhadap reliabilitas instrument. Reliabilitas yang dihitung hanya untuk butir-butir yang tidak gugur (valid). Dengan kata lain, butir-butir yang tidak valid tidak diikutsertakan dalam pengujian atau perhitungan reliabilitas (Koyan, 2011: 135). Dalam penelitian ini, untuk menentukan reliabilitas kemampuan berpikir kritis yang sifatnya politomi digunakan Alpha Cronbach dengan rumus sebagai berikut.

$$
\mathrm{r}_{1.1}=\left(\frac{k}{k-1}\right)\left(\frac{S D^{2}{ }_{t o t}-\sum S D_{i}{ }^{2}}{S D_{t o t}{ }^{2}}\right)
$$

(Koyan, 2011: 135)

Selanjutnya hasilperhitungan atau pengujian reliabilitas yang telah diperoleh dibandingkan dengan kriteria reliabiltas. Berdasarkan cara perhitungan reliabilitas yang sama, maka untuk analisis koefisien korelasi pada butir-butir kemampuan berpikir kritis selanjutnya dianalisis dengan komputer. Perhitungan menggunakan bantuan komputer paket program Microsoft Office Excel 2007. Langkah ini dilakukan untuk medapatkan hasil perhitungan dalam kurun waktu yang singkat.

Uji reliabilitas yang dapat digunakan untuk menguji butir soal hasil belajar adalah formula atau rumus KR-20. K-R singkatan dari Kuder dan Richardson, sedangkan 20 merupakan catatan bilangan yang menemukan banyak replikasi perhitungan sampai penemuan rumus tersebut.

\section{HASIL DAN PEMBAHASAN}

\section{Validitas dan Reliabilitas Instrumen Kemampuan Berpikir Kritis}

Intrumen yang digunakan dalam penelitian ini meliputi lembar validasi intrumen kemampuan berpikir kritis dan kemampuan literasi sains. Setelah produk awal dapat dijalankan dengan lancar, dilanjutkan pada tahap validasi, yaitu validasi oleh ahli dan praktisi dilanjutkan revisi produk tahap pertama, kemudian dilakukan uji validitas konten dilanjutkan revisi produk akhir. Deskripsi data hasil uji ahli dan praktisi dipaparkan pada tabel berikut.

Tabel 1. Perhiungan Validitas Isi Kemampuan Berpikir Kritis

\begin{tabular}{|c|c|c|c|c|}
\hline No Butir & Relevan & Tidak Relevan & CVR & Status \\
\hline 1 & 5 & 0 & 1 & Valid \\
\hline 2 & 5 & 0 & 1 & Valid \\
\hline 3 & 5 & 0 & 1 & Valid \\
\hline 4 & 5 & 0 & 1 & Valid \\
\hline 5 & 5 & 0 & 1 & Valid \\
\hline 6 & 5 & 0 & 1 & Valid \\
\hline 7 & 5 & 0 & 1 & Valid \\
\hline 8 & 5 & 0 & 1 & Valid \\
\hline 9 & 5 & 0 & 1 & Valid \\
\hline 10 & $\begin{array}{l}5 \\
\sum^{2} \mathrm{CVR}\end{array}$ & 0 & 10 & Valid \\
\hline
\end{tabular}

1) Menghitung Isi Validity Index (CVI)

$$
=1
$$

Berdasarkan hasil validasi ahli dan praktisi dengan rincian 2 validasi ahli dari pakar (dosen) yang membidangi pengembangan instrumen kemampuan berpikir kritis dan 3 orang guru kelas IV SD maka diperoleh hasil perhitungan dengan rumus Lawshe. Berdasarkan hasil perhitungan tersebut diperoleh hasil
1,00 dikategorikan ke klasifikasi valid tanpa perlu direvisi lagi.

Selanjutnya dilakukan Uji reliabilitas instrumen kemampuan berpikir kritis pada muatan pembelajaran IPA kelas IV SD diuji oleh 5 pakar yaitu 2 ahli dan 3 praktisi (guru). Nilai-nilai untuk pengujian reliabilitas diambil dari skor-skor item kemampuan berpikir kritis yang 
dinyatakan valid atau terpakai. Item yang tidak valid tidak dilibatkan dalam pengujian reliabilitas. Dalam hal ini semua butir insturmen kemampuan berpikir kritis dinyatakan valid, maka dari itu semua instrumen kemampuan berpikir kritis dapat di uji reliabilitasnya.

Uji reliabilitas instrumen kemampuan berpikir kritis diuji dengan menggunakan teknik formula Alpha Cronbach. Menurut Arikunto (2009), rumus Alpha Cronbach digunakan untuk mencari reliabillitas instrumen yang skornya bukan 1 dan 0 , seperti angket atau soal bentuk uraian. Table kerja untuk menghitung reliabilitas instrumenkemampuan berpikir kritis dengan 5 pakar menggunakan rumus
Alpha Cronbach Berdasarkan hasil perhitungan diperoleh nilai kemampuan berpikir kritis yang valid, kofisien reliabilitas sebesar 0,92 berada pada kategori sangat tinggi.

\section{Validitas dan Reliabilitas Instrumen Kemampuan Literasi Sains}

Instrumen yang dikembangkan dalam penelitian ini adalah instrumen kemampuan literasi sains kelas IV SD. Instrumen kemampuan literasi sains tersebut diuji validasi oleh 5 pakar yaitu 2 ahli dan 3 praktisi (guru). Deskripsi kriteria penggolongan validitas uji judges instrumen kemampuan literasi sains dengan 5 pakar dipaparkan pada tabel 02 . sebagai berikut.

Tabel 2. Perhiungan Validitas Isi Kemampuan Literasi Sains

\begin{tabular}{|c|c|c|c|c|}
\hline No Butir & Relevan & Tidak Relevan & CVR & Status \\
\hline 1 & 5 & 0 & 1 & Valid \\
\hline 2 & 4 & 1 & 0,6 & Valid \\
\hline 3 & 3 & 2 & 0,2 & Valid \\
\hline 4 & 4 & 1 & 0,6 & Valid \\
\hline 5 & 4 & 1 & 0,6 & Valid \\
\hline 6 & 5 & 0 & 1 & Valid \\
\hline 7 & 5 & 0 & 1 & Valid \\
\hline 8 & 4 & 1 & 0,6 & Valid \\
\hline 9 & 4 & 1 & 0,6 & Valid \\
\hline 10 & 5 & 0 & 1 & Valid \\
\hline 11 & 5 & 0 & 1 & Valid \\
\hline 12 & 4 & 1 & 0,6 & Valid \\
\hline 13 & 5 & 0 & 1 & Valid \\
\hline 14 & 5 & 0 & 1 & Valid \\
\hline 15 & 5 & 0 & 1 & Valid \\
\hline 16 & 4 & 1 & 0,6 & Valid \\
\hline 17 & 5 & 0 & 1 & Valid \\
\hline 18 & 3 & 2 & 0,2 & Valid \\
\hline 19 & 5 & 0 & 1 & Valid \\
\hline 20 & 5 & 0 & 1 & Valid \\
\hline 21 & 4 & 1 & 0,6 & Valid \\
\hline 22 & 5 & 0 & 1 & Valid \\
\hline 23 & 3 & 2 & 0,4 & Valid \\
\hline 24 & 5 & 0 & 1 & Valid \\
\hline 25 & 5 & 0 & 1 & Valid \\
\hline 26 & 4 & 1 & 0,6 & Valid \\
\hline 27 & 4 & 1 & 0,6 & Valid \\
\hline 28 & 4 & 1 & 0,6 & Valid \\
\hline 29 & 4 & 1 & 0,6 & Valid \\
\hline 30 & 4 & 1 & 0,6 & Valid \\
\hline & $\sum$ CVR & & 22,6 & \\
\hline
\end{tabular}


Berdasarkan hasil uji validitas content pengembangan produk instrumen Kemampuan Literasi Sains dengan 5 pakar yakni 2 dosen ahli dan 3 praktisi (guru) menggunakan rumus lawshe mendapatkan hasil bahwa semua butir instrumen kemampuan literasi sains dikategorikan valid dan layak digunakan tanpa perlu direvisi kembali. Kemudian melakukan perhitungan isi validity index instrumen kemampuan literasi sains yang di kembangkan mendapatkan hasil sebesar $\mathrm{CVI}=0,76$. Hal ini berarti, instrumen kemampuan literasi sains yang di kembangkan termasuk ke dalam kriteria valid.

Setelah uji validitas selanjutnya dilakukan uji reliabilitas. Berdasarkan data di atas, dapat dihitung reliabilitas instrumen kemampuan literasi sains 0.94 Jadi, dengan menggunakan formula KR-20. Reliabilitas instrumen kemampuan literasi sains adalah 0.94. Dengan demikian, dapat disimpulkan bahwa semua butir soal tersebut telah memiliki reliabilitas yang sangat tinggi.

Hasil-hasil penelitian yang telah dilakukan akan dipaparkan pada pembahasan. Adapun hasil penelitian yang dibahas meliputi validitas intrumen kemampuan berpikir kritis dan kemampuan literasi sains kelas IV SD dan Reliabilitas instrumen kemampuan berpikir kritis dan kemampuan literasi sains.

\section{Validasi Intrumen Kemampuan Berpiki Kritis}

Validasi intrumen kemampuan berpikir kritis ditempuh melalui dua tahapan validasi yaitu validasi ahli dan praktisi Validasi dilakukan oleh 2 orang pakar yang berasal dari kalangan dosen yang berkopenten di bidangnya dan 3 orang praktisi yang berasal dari guru kelas IV SD. Hasil perhitungan validasi ahli dan praktisi hasil yang didapat pada pengembangan produk instumen kemampuan berpikir kritis capaiannya 1.00. Berdasarkan perhitungan tersebut, maka instrumen kemampuan berpikir kritis telah memenuhi validasi atau valid, hal ini sejalan dengan penelitian yang dilakukan oleh Mukti \& Istiyono (2018), hasil penelitian menunjukkan bahwa (a)Intstrumen tes memenuhi syarat validitas isi expert judgment dan memperoleh bukti empiris kecocokan model (goodness of fit tes) pada model PCM (Partial Credit Model) berdasarkan skor politomus empat kategori, (b) Instrument tes mempunyai tingkat kesulitan yang baik dengan rentang nilai 2,00 dan 2,00.(c) Instrumen tes mempunyai nilai reliabilitas yang tinggi yaitu sebesar 0,86 sehingga instrumen tes berpikir kritis memenuhi syarat sebagai alat ukur yang baik. (d) Instrumen tes dapat digunakan untuk mengukur kemampuan berpikir kritis dengan rentang kemampuan sebesar -3,7 sampai dengan 2,90.

Selanjutnya penelitian yang dilakukan oleh Trimawati \& Raharjo (2020), hasil penelitian menunjukkan bahwa (a) perangkat pembelajaran dan instrumen penilaian IPA Terpadu yang dikembangkan berkategori sangat valid dengan nilai modus 5, (b) kegiatan pembelajaran terlaksana sangat baik dengan nilai modus 5, (c) aktivitas siswa dalam pembelajaran terlaksana sangat baik dengan nilai modus 5, (d) respon siswa terhadap pembelajaran proyek cukup baik dengan kisaran angka antara $50 \%-60 \%$, dan (e) hasil tes berpikir kritis dan kreatif siswa ada peningkatan yang baik pula, kemampuan berpikir kritis meningkat dari 25,85 (Kurang Kritis) menjadi 87,76 (Sangat Kritis) dan kemampuan berpikir kreatif meningkat dari 20,44 (Kurang Kreatif) menjadi 84,85 (Sangat Kreatif). Simpulan pengembangan perangkat pembelajaran dan instrumen penilaian IPA Terpadu dalam pembelajaran Project Based Learning yang dikembangkan layak digunakan untuk meningkatkan kemampuan berpikir kritis dan kreatif siswa.

Diperolehnya intrumen kemampuan berpikir kritis di kelas IV yang sangat baik dan sangat layak digunakan disebabkan oleh beberapa faktor. Produk instrumen kemampuan berpikir kritis sesuai dengan aspek-aspek pengukuran validatas yaitu validitas isi. Produk intsrumen memenuhi validitas isi berarti dalam 
pengembangannya telah didasarkan atas isi dari teori-teori yang dijadikan acuan dalam perumusan ataupun penyusunan. Sedangkan produk instumen yang memenuhi validitas konstruk berarti dalam pengembangannya memperhatikan keterkaitan antara materi, kurikulum 2013 dan aspek-aspek kemampuan berpikir kritis. Hal tersebut dapat mengarahkan siswa untuk mampu memahami materi atau konsep yang dipelajari, dan meningkatkan kemampuan berpikir. Selain itu intrumen berfungsi untuk memahami dan mengarahkan potensi dari seorang peserta didik agar dapat menggali terus potensinya dan memperbaiki kelemahannya. Sedangkan untuk peserta didik, kurikulum berfungsi untuk membantu mereka agar dapat memahami materi dan melaksanakan proses pembelajaran dengan mudah, sehingga target pembelajaran dapat tercapai. Tujuan utama kurikulum adalah untuk mempersiapkan peserta didik agar dapat menjadi pribadi serta warga negara yang kreatif, inovatif, beriman, dan juga afektif ketika dia berada pada lingkungan masyarakat kelak.Selain itu, peserta didik juga diharapkan mendapatkan pengalaman baru yang bisa saja menjadi bekal di kehidupannya nanti.

Faktor-faktor tersebut diatas menyebabkan produk instrument kemampuan berpikir kritis yang dikembangkan telah memenuhi kriteria sangat baik sesuai dengan yang diharapkan, baik dari segi isi dan konstruk sehingga sangat layak untuk digunakan dalam pembelajaran.

\section{Reliabilitas Intrumen Kemampuan Berpikir Kritis}

Reliabiltas instrumen mengacu pada konsistensi hasil pengukuran yang ditunjukkan oleh instrumen tersebut. Instrumen yang memiliki reliabiltas yang tinggi akan memberikan hasil yang relatif sama, sekalipun instrumen tersebut digunakan dalam kurun waktu yang berbeda. Reliabilitas instrumen kemampuan berpikir kritis dilakukan dengan formula Alpha Cronbach karena pada dasarnya formula Alpha Cronbach lebih umum diterapkan untuk menghitung reliabilitas tes politomi. Sejalan dengan Arikunto (2009), rumus Alpha Cronbach digunakan untuk mencari reliabillitas instrumen yang skornya bukan 1 dan 0 , seperti angket atau soal bentuk uraian. Berdasarkan reliabilitas intrumen kemampuan berpikir kritis setelah dihitung memperoleh hasil 0.92 dengan kategori sangat tinggi. Dwipayani (dalam Khoiriah 2018) juga menjelaskan tentang soal perangkat yang dinyatakan berkualitas baik jika memiliki indeks validitas dan reliabilitas yang tinggi.

\section{Validasi Intrumen Kemampuan Literasi Sains}

Setelah dilakukan analisis terhadap validitas intrumen kemampuan literasi sains kelas IV SD. Hasil menunjukkan bahwa intrumen kemampuan literasi sains valid untuk digunakan dalam evaluasi pembelajaran untuk mengetahui kemampuan yang dimiliki siswa. Sejalan dengan teori Benyamin Bloom dalam Wardani, N. S., dkk (2012:193) menyatakan bahwa, ranah kognitif adalah kemampuan intelektual siswa dalam berpikir mengetahui dan memecahkan masalah. Dengan kata lain, beliau mengungkapkan bahwa proses kognitif yang menunjukkan keterampilan berpikir sesuai revisi taksonomi bloom diformulasikan menjadi 6 kategori yaitu, mengingat, memahami, menerapkan, mengevalusi, dan menciptakan. Penilaian pengetahuan atau kognitif berdasarkan permendikbud nomor 23 tahun 2016 tentang standar penilaian pendidikan merupakan kegaiatan yang dilakukan untuk mengukur penguasaan pengetahuan peserta didik. Jadi, dapat disimpulkan bahwa pengembangan intrumen kemampuan literasi sains sesuai dengan kemampuan berpikir yang telah dicetuskan oleh taksonomi bloom.

Validasi intrumen kemampuan literasi sains kelas IV SD ditempuh melalui dua tahapan validasi yaitu validasi ahli dan praktisi Validasi dilakukan oleh 2 orang pakar yang berasal dari kalangan dosen yang berkopenten di bidangnya dan 3 orang praktisi yang berasal dari guru kelas IV SD. Rata-rata skor validitas berdasarkan hasil validasi ahli dan 
praktisi hasil yang didapat pada pengembangan produk intumen kemampuan literasi sains kelas IV SD capaiannya 0,75 . Secara keseluruhan intumen kemampuan literasi sains kelas IV SD dikategorikan sangat baik dan sangat layak digunakan dengan tidak perlu direvisi.

Hasil penelitian tersebut sejalan dengan (Utami \& Wardani, 2020), (1) cara mengembangkan intrumen penilaian kognitif yaitu menentukan tema, $\mathrm{KI}, \mathrm{KD}$, IPK, tujuan pembelajaran, alat ukur, kisikisi, butir soal, uji coba, revisi dan menentukan produk akhir, (2) intrumen butir soal berbentuk PG terdiri dari 42 butir. Berdasarkan analisis secara klasik, butir soal memiliki validitas tinggi $r \geq 0,20$, reliabilitas $\alpha \geq 0,20 \quad(\alpha=938)$, tingkat kesukaran sedang, daya pembeda diterima, daya pengecoh sangat baik, dan baik. Penilaian jika diterapkan dengan benar dapat meningkatkan kualitas pembelajaran. Lebih lanjut relevan dengan pernyataan berikut,

How making your own assessments improve your teaching: (1) knowing how to choose or to craft quality assessments increases the qua-lity of your teaching decisions; (2) what and how you assess communicated in a powerful way what you really value in your students learning; (3) when you carefully define assessment tasks, you are clarifying what you want students to learn; (4) you use your knowledge of how to craft quality assessment tasks when you evaluate assessment materials available from other source; (5) learning to craft assessment tasks increases your freedom to design lesson; 6) you will improve the validity of your interpretations and uses of assessment result. (Nitko. \& Brookhart, (dalam Suryani ,2017).

Merujuk pendapat di atas dapat ditarik simpulan bahwa, penilaian tidak hanya berpengaruh terhadap keberhasilan siswa tetapi penilaian dapat meningkatkan kualitas guru dalam mengajar. Penilaian juga menjelaskan apa yang dibutuhkan peserta didik, hasil dari penilaian dapat meningkatkan validitas interpretasi guru terhadap siswa sehingga penilaian berpengaruh terhadap peningkatan kualitas pembelajaran. Instrumen yang baik dan layak digunakan harus sudah divalidasi. Suryani (2017) Tujuan dari validasi adalah untuk mendapatkan umpan balik, kritik saran tentang peningkatan model sesuai dengan bidang keahlian masing-masing pelaku validasi. Validitas ahli bertujuan untuk memberikan penilaian terhadap item dalam instrumen. Penilaian berkaitan dengan kemampuan poin terhadap indikator.

\section{Reliabilitas Intrumen Kemampuan Literasi Sains}

Uji Reliabilitas yang dapat digunakan untuk menguji butir soal kemampuan literasi sains adalah formula atau rumus $\mathrm{KR}-20$. K-R singkatan dari Kuder dan Richardson, sedangkan 20 merupakan catatan bilangan yang menemukan banyak replikasi perhitungan sampai penemuan rumus tersebut. Skor kemampuan literasi sains merupakan skor dikotomi. Berdasarkan hasil perhitungan uji reliabilitas kemampuan literasi sains diperoleh hasil 0,94 berada pada kategori sangat tinggi. Artinya sesuai hasil yang diperoleh instrumen kemampuan literasi sains layak digunakan di Sekolah Dasar.

\section{PENUTUP}

Penelitian ini dilakukan berangkat dari adanya permasalahan dalam instrumen yang digunakan pada jenjang anak Sekolah Dasar. Permasalahan yang dimaksud adalah (1) pencapaian tujuan pembelajaran untuk mata pelajaran IPA SD masih tergolong relatif rendah dibandingkan dengan mata pelajaran lainnya hal ini dikarenakan kurangnya penyerapan materi dalam mengikuti pembelajaran, (2) kurang adanya memunculkan keterampilan berpikir kritis dalam mengembangkan potensi siswa ada pelajaran IPA, (3) instrumen asesmen yang dibuat oleh guru masih terbatas pada tingkat pengetahuan (C1) dan pemahaman (C2), belum mengukur keterampilan berpikir tingkat tinggi, (4) instrumen ssesmen kemampuan berpikir kritis siswa belum pernah dikembangkan oleh guru. Untuk itu guru perlu 
mengembangkan intrumen untuk mengukur keberhasilan siswa mencapai tujuan pembelajaran yang bermakna salah satu instrumen yang dapat meningkatkan kemampuan berpikir tingkat tinggi yaitu kemampuan berpikir kritis.

Berdasarkan laporan hasil penelitian seperti yang telah dipaparkan pada bagian sebelumnya, maka dapat disimpulkan beberapa hasil penelitian sebagai berikut. (1) Instrumen kemampuan berpikir kritis yang dikembangkan memenuhi syarat validitas konten dengan nilai 1.00dengan kategori sangat baik dan sangat layak digunakan.

(2) Instrumen berpikir kritis yang dikembangkan memenuhi syarat reliabilitas expert dengan nilai 0,92 dengan kategori sangat tinggi sehingga layak digunakan dalam pembelajaran. (3) Instrumen kemampuan literasi sains yang dikembangkan memenuhi syarat validitas konten dengan nilai 0,76 yang dinyatakan valid sehingga layak digunakan dalam pembelajaran. (4) Instrumen kemampuan literasi sains yang dikembangkan memenuhi syarat reliabilitas expert dengan nilai 0,94 dengan kategori sangat tinggi sehingga layak digunakan dalam pembelajaran.

Mengacu pada rumusan masalah dan didukung oleh laporan hasil penelitian dalam penelitian ini, dapat diajukan saran sebagai berikut. Bagi guru, hendaknya benar-benar paham bagaimana langkah-langkah dalam menysun instrumen yang berkualitas dengan memperhatikan $\mathrm{KD}$, indikator mengacu ke Lower and Higher Order Thinking Skills (L\&HOTS), yakni skala C1, C2, C3, dan C4 pada taksonomi Bloom. Di samping itu, persyaratan instrument dari sisi (a) substansi, yakni merepresentasikan kompetensi yang dinilai; (b) konstruksi, yakni memenuhi persyaratan teknis sesuai dengan bentuk instrumen yang digunakan; dan (c) bahasa, yakni menggunakan bahasa yang baik dan benar serta komunikatif sesuai dengan taraf perkembangan peserta didik dapat dipahami dengan baik oleh peserta. Bagi Kepala Sekolah, sebaiknya memberikan stimulus kepada guru-guru dengan melaksanakan kegiatan diklat, bimtek, workshop dan lain-lain guna memberikan pelatihan yang dapat menambah wawasan guru terkait dengan penyusunan instrumen dengan semaksimal mungkin. Selain hal tersebut, Kepada Sekolah perlu melakukan penilaian terhadap kinerja guru, serta memberikan bimbingan secara khusus. Bagi Peneliti lain, Kepada peneliti lain disarankan agar hasil penelitian ini dapat digunakan sebagai acuan kepustakaan untuk melakukan penelitian dalam variabel yang sama dan memperhatikan kendala-kendala yang dialami dalam penelitian ini sebagai bahan pertimbangan untuk perbaikan dan penyempurnaan yang akan dilaksanakan. Pengembangan dari keterbatasan penelitian ini, karena penelitian yang dilakukan baru sampai pada tahapan development (pengembangan). Tahapan lebih lanjut dapat dilakukan sampai disseminate (penyebaran) produk.

\section{DAFTAR RUJUKAN}

Arikunto, Suharsimi. 2009. Dasar-dasar evaluasi pendidikan. Jakarta: PT Bumi Aksara.

Azwar, Saifuddin. 2013. Reliabilitas dan Validitas. Yogyakarta: Pustaka Pelajar.

Candiasa, I.M. 2010.Pengujian Instrumen Penelitian Disertai Aplikasi ITEMAN DAN BIGSTEP. Singaraja: Unit Penerbitan Universitas Pendidikan Ganesha.

Dantes, N. 2012.Metodologi Penelitian. Yogyakarta: Andi. ISBN: 978-97929-3463-2.

Djamarah, S. B dan Zain, A. 2006.Stategi Belajar Mengajar. Jakarta: Rimeka Cipta.

Guo,L. 2020. Scientific Literacy and 21 Century paradigm: Faculty of Education University of Prince Edward Island. Vol 1, No 2. Tersedia pada International Journal of Social Science Research. Diakses 2 Januari 2021 
Maulidati.S. $2018 . \quad$ "Pengaruh Pembelajaran Berbendekatan Saintifik Berorientasi Science Environment Technology Society Terhadap Kemampuan Berpikir Kritis dan Hasil Belajar IPA Siswa Kelas V". Jurnal Pendidikan Dasar Indonesia. Volume 2 Nomor 2.

Roestiyah. 2008. Strategi Belajar Mengajar. Jakarta: PT Rineka Cipta.

Samatowa, Usman. 2011. Pembelajaran IPA di Sekolah Dasar. Jakarta: PT Indeks.

Sumayasa, I Nyoman.2015. Pengaruh Implementasi Pendekatan Saintifik Terhadap Motivasi Belajar dan Hasi Belajar IPA Pada Siswa Kelas VI di Sekolah Dasar Gugus VI Kecamatan Abang Karangasem.E-jurnal Program pascasarjana Universitas Pendidikan Ganesha.Volume 5.

Suryani, Helmiah. 2017. “ Development and Validity of Mathematical Learning Assessment Instruments Based on Multiple Intelligence". Jurnal Penelitian dan Evaluasi Pendidikan. Volume 21 No 1.

Trimawati, Karina, dkk. 2020. "Pengembangan Intrumen Penilaian IPA Terpadu dalam Pembelajaran Model Project Based Learning (PjBL) untuk Meningkatkan Kemampuan Berpikir Kritis dan Kreatif Siswa SMP". Quantum: Jurnal Inovasi Pendidikan Sains, Vol. 11, No. 1, 2020, 36-52.

Utami, Diah Ayu Putri, Wardani, Naniek Sulistya. 2020. "Pengembangan Intrumen Penialain Kognitif dalam Pembelajaran Tematik Kelas 5 SD". Lentera: Jurnal IImiah Kependidikan, Vol. 13, No. 1 (2020), 1-18.
Wardani, Naniek Sulistya, dkk. 2012. Assesmen Pembelajaran SD. Kabupaten Semarang: Widya Sari Press. 